\title{
PENGARUH DANA DESA TERHADAP KEMISKINAN: STUDI TINGKAT KABUPATEN/KOTA DI INDONESIA
}

\author{
Tri Angga Sigit \\ Direktorat Jenderal Perbendaharaan \\ Ahmad Kosasih \\ Badan Pusat Statistik \\ Alamat Korepondensi: hanif643@gmail.com
}

\begin{abstract}
National development in general aims to improve people's welfare as measured by poverty indicators. In reducing poverty, one focus of the government is to reduce poverty in rural areas that have a higher percentage than urban areas. One of the government spending aimed at reducing poverty in rural areas is the Village Fund. This study aims to determine the effect of the Village Fund on poverty at the Regency/City level in Indonesia. This study uses quantitative data that focuses on economic variables consisting of the Total Poor Population as the dependent variable and the Village Fund as the main independent variable. In addition, Village Fund Allocation, Gross Regional Domestic Product, and Capital Expenditures are used as other independent variables. As a material for analysis and compiling recommendations, qualitative data in this study were used in the form of in-depth interviews with the Directorate General of Fiscal Balance and the Fiscal Policy Office. The analytical method used is panel data regression with the Fixed Effect Model. The result shows that the Village Fund variable has a negative effect on the Total Poor Population. This shows that the Village Fund is able to effectively reduce the number of poor people. However, based on the results of in-depth interviews, there are at least three aspects of the Village Fund policy that need to be improved namely covering improvements to the formulation aspects, aspects of strengthening supervision, and aspects of increasing innovation in the use of Village Funds.
\end{abstract}

\section{KATA KUNCI:}

Dana Desa, Kemiskinan

\section{ABSTRAK}

Pembangunan nasional secara umum bertujuan untuk meningkatkan kesejahteraan rakyat yang dapat diukur dengan indikator kemiskinan. Dalam mengurangi kemiskinan, salah satu fokus pemerintah adalah mengurangi kemiskinan di wilayah desa yang memiliki persentase lebih tinggi dibandingkan perkotaan. Salah satu belanja pemerintah yang ditujukan untuk mengurangi kemiskinan di desa adalah belanja Dana Desa. Penelitian ini bertujuan untuk mengetahui pengaruh Dana Desa terhadap kemiskinan di tingkat Kabupaten/Kota di Indonesia. Penelitian ini menggunakan data kuantitatif yang berfokus pada variabel ekonomi yang terdiri dari Jumlah Penduduk Miskin sebagai variabel dependen dan Dana Desa sebagai variabel independen utama. Selain itu, digunakan Alokasi Dana Desa, Produk Domestik Regional Bruto, dan Belanja Modal sebagai variabel independen lainnya. Sebagai bahan analisis dan menyusun rekomendasi, pada penelitian ini digunakan data kualitatif berupa wawancara mendalam pada Ditjen Perimbangan Keuangan dan Badan Kebijakan Fiskal. Metode analisis yang digunakan adalah regresi data panel dengan Fixed Effect Model. Hasil penelitian menemukan bahwa variabel Dana Desa memiliki pengaruh negatif terhadap Jumlah Penduduk Miskin. Hal tersebut menunjukkan bahwa Dana Desa mampu secara efektif menurunkan Jumlah Penduduk Miskin. Namun berdasarkan hasil wawancara mendalam, minimal terdapat tiga aspek dari kebijakan Dana Desa yang perlu diperbaiki yaitu meliputi penyempurnaan aspek formulasi, aspek penguatan pengawasan, dan aspek peningkatan inovasi dalam penggunaan Dana Desa.

\section{KLASIFIKASI JEL:}

I38

\section{CARA MENGUTIP:}

Sigit, T. A., \& Kosasih, A. (2020). Pengaruh dana desa terhadap kemiskinan: studi tingkat kabupaten/kota di Indonesia. Indonesian Treasury Review: Jurnal Perbendaharaan, Keuangan Negara dan Kebijakan Publik, 5(2), 105-119. 


\section{PENDAHULUAN}

\subsection{Latar Belakang}

Indonesia merupakan Negara Kesatuan yang dibagi atas daerah-daerah provinsi dan daerah provinsi itu dibagi atas kabupaten dan kota di mana setiap provinsi, kabupaten, dan kota memiliki pemerintahan daerah yang diatur dengan Undang-Undang (Pasal 18 UUD 1945). Dengan kewenangan berdasarkan Undang-Undang yang dimilikinya, pemerintahan provinsi dan kabupaten/kota melakukan kegiatan pembangunan lingkup daerahnya masing-masing yang dilaksanakan oleh struktur pemerintahan terkait. Susilowati \& Hadi (2017, hal. 514) menyebutkan bahwa pembangunan daerah merupakan bagian integral dalam pembangunan nasional sehingga pelaksanaan pembangunan nasional dan pembangunan daerah harus bersinergi untuk mencapai tujuan pembangunan.

Pembangunan nasional secara umum bertujuan untuk meningkatkan kesejahteraan rakyat. Dalam mencapai tujuan tersebut, pemerintah masih menghadapi berbagai kondisi yang tidak ideal sehingga menghambat tercapainya tujuan pembangunan. Salah satu kondisi tidak ideal tersebut adalah kemiskinan yang masih relatif tinggi di berbagai daerah. Suliswanto (2010, hal. 358) mendefinisikan kemiskinan sebagai suatu standar tingkat hidup yang rendah yang ditandai dengan adanya suatu kekurangan pada tingkat materi dibandingkan dengan tingkat standar hidup yang berlaku umum pada suatu lingkungan masyarakat. Dalam mengukur kemiskinan, Badan Pusat Statistik (BPS) menggunakan konsep kemampuan seseorang untuk memenuhi kebutuhan dasar (basic needs approach). Dengan pendekatan tersebut, kemiskinan dipandang sebagai ketidakmampuan untuk memenuhi kebutuhan dasar baik berupa makanan maupun bukan makanan. Saputra, \& Mudakir (2011, hal. 2) menyebutkan bahwa kemiskinan dapat menjadi salah satu tolak ukur kondisi sosial ekonomi dalam menilai keberhasilan pembangunan yang dilakukan pemerintah di suatu daerah di mana tingkat kemiskinan yang tinggi dapat menimbulkan berbagai dampak negatif seperti masalah sosial dan masalah ekonomi.

Berdasarkan data Badan Pusat Statistik (BPS), jumlah penduduk miskin cenderung mengalami stagnasi dari tahun 2012 sampai dengan tahun 2014 dan terjadi kenaikan pada tahun 2015. Setelah tahun 2015, jumlah penduduk miskin kembali cenderung mengalami penurunan sampai dengan tahun 2017. Dalam empat tahun terakhir, persentase penduduk miskin turun menjadi sebesar 10,12 persen.
Tabel 1. Jumlah Penduduk Miskin di Indonesia (Semester 2) Tahun 2012 s.d. 2017

\begin{tabular}{ccc}
\hline Tahun & $\begin{array}{c}\text { Jumlah } \\
\text { Penduduk } \\
\text { Miskin } \\
\text { (Juta) }\end{array}$ & $\begin{array}{c}\text { Persentase } \\
\text { (\%) }\end{array}$ \\
\hline 2012 & 28,59 & 11,66 \\
\hline 2013 & 28,55 & 11,47 \\
\hline 2014 & 27,73 & 10,96 \\
\hline 2015 & 28,51 & 11,13 \\
\hline 2016 & 27,76 & 10,70 \\
\hline 2017 & 26,58 & 10,12 \\
\hline
\end{tabular}

(Sumber: BPS, 2019)

Usaha pemerintah untuk terus mengurangi kemiskinan tidak terlepas dari berbagai kebijakan baik yang terkait ekonomi makro maupun ekonomi mikro (Bappenas, rilis tanggal 19 Juli 2018). Pada tataran ekonomi makro, pemerintah terus mendorong pertumbuhan ekonomi, menjaga stabilisasi harga dan membuka lapangan kerja. Pemerintah juga terus mengembangkan infrastruktur daerah tertinggal sehingga kegiatan ekonomi di daerah tersebut dapat lebih bergerak maju. Terkait dengan ekonomi mikro, pemerintah memberikan bantuan langsung baik terkait pangan, subsidi tunai maupun bantuan iuran asuransi kesehatan bagi masyarakat miskin. Hal tersebut merupakan implementasi kebijakan pro poor budget yang dilakukan oleh pemerintah dimana pemerintah menggunakan belanja dalam Anggaran Pendapatan Belanja Negara (APBN) sebagai alat untuk mengurangi kemiskinan. Rinusu (2006, hal. 2) mendefinisikan pro poor budget sebagai anggaran yang berpihak kepada rakyat miskin dalam bentuk melaksanakan perencanaan dan penganggaran yang secara sengaja ditujukan untuk membuat kebijakan, program, dan kegiatan yang dampaknya dapat meningkatkan kesejahteraan atau terpenuhinya kebutuhan hakhak dasar masyarakat.

\subsection{Rumusan Masalah}

Dalam mengurangi kemiskinan, salah satu fokus pemerintah adalah mengurangi kemiskinan di wilayah desa. Hal ini tidak terlepas karena sampai dengan saat ini, tingkat kemiskinan di wilayah desa lebih tinggi dibandingkan di wilayah kota (BPS, 2019, hal. 237). Program Nawacita Presiden Joko Widodo yang ingin mengejar ketertinggalan pembangunan di daerah pinggiran (desa) merupakan wujud nyata dari usaha pemerintah untuk mengurangi kemiskinan di wilayah desa.

Salah satu belanja pemerintah pusat yang ditujukan untuk mengurangi kemiskinan di desa adalah belanja Dana Desa yang disalurkan pemerintah mulai tahun 2015 sebagai amanah dari disahkannya Undang-Undang Nomor 6 Tahun 2014 tentang Desa. Dengan adanya penyaluran Dana 
Desa diharapkan kemiskinan di kabupaten/kota secara keseluruhan dapat dikurangi.

Turunnya jumlah penduduk miskin dalam rentang tahun 2015 sampai dengan 2017 menarik minat penulis untuk meneliti apakah terdapat peran Dana Desa dalam mengurangi kemiskinan kabupaten/kota di Indonesia. Dengan demikian tujuan penelitian ini adalah untuk menganalisis apakah Dana Desa memiliki pengaruh dalam mengurangi kemiskinan di tingkat kabupaten/kota di Indonesia.

Selain Dana Desa, penulis menambahkan variabel dari segi ekonomi yaitu Alokasi Dana Desa (ADD), Produk Regional Domestik Bruto (PDRB) dan Belanja Modal APBD kabupaten/kota. Alokasi Dana Desa memiliki pengaruh terhadap Kemiskinan berdasarkan penelitian Prasetyanto (2012) yang menyimpulkan bahwa peningkatan Alokasi Dana Desa mampu menurunkan Kemiskinan di perdesaan. Sementara itu, PDRB memiliki pengaruh terhadap Kemiskinan berdasarkan penelitian Dama, Lapian, \& Sumual (2016, hal. 558) yang menyimpulkan bahwa PDRB berpengaruh negatif terhadap tingkat kemiskinan di Kota Manado. PDRB merupakan salah satu ukuran pertumbuhan ekonomi di suatu daerah di mana ketika terjadi peningkatan pada pertumbuhan ekonomi maka rata-rata pengeluaran perkapita juga akan meningkat dan peningkatan tersebut akan sejalan dengan penurunan kemiskinan (Nanga, 2006, hal. 134). Belanja Modal memiliki pengaruh terhadap kemiskinan di kabupaten/kota berdasarkan penelitian yang dilakukan oleh Widianto, Sedyautami \& Nurmansyah (2016, hal. 174) dan Susilowati \& Hadi (2017, hal. 523). Adanya Belanja Modal dapat mendorong penyediaan infrastruktur baik fisik maupun non fisik sehingga dapat mendorong kegiatan perekonomian dan dengan kegiatan perekonomian yang terus bergerak maka tingkat kemiskinan akan dapat dikurangi. Widianto, Sedyautami, \& Nurmansyah (2016, hal. 174) dalam penelitiannya menyimpulkan bahwa Belanja Modal berpengaruh terhadap Kemiskinan di Kota Tegal sedangkan Susilowati, \& Hadi (2017, hal. 523) dalam penelitiannya menyimpulkan bahwa Belanja Modal memiliki pengaruh terhadap Kemiskinan di Provinsi Jawa Timur.

Berdasarkan hal-hal tersebut, penelitian ini memiliki fokus tujuan untuk menganalisis pengaruh Dana Desa terhadap Kemiskinan Kabupaten/Kota di Indonesia dengan menambahkan variabel Alokasi Dana Desa, PDRB dan Belanja Modal APBD Kabupaten/Kota sebagai tambahan analisis penelitian.

\section{TINJAUAN PUSTAKA}

\subsection{Dana Transfer}

Transfer antar level pemerintahan merupakan bagian yang tidak terpisahkan dari sebuah negara dengan multi layers pemerintahan dalam wujud adanya sistem perimbangan keuangan antara pusat dan daerah. Rozani (2017, hal. 2) menyebutkan ada dua alasan yang menyebabkan timbulnya transfer dari pemerintah pusat ke daerah yaitu pertama, adanya amanat undang-undang yang melandasi keuangan pemerintah pusat dan daerah dan kedua, adanya argumen teoritik yang mengaitkan kewenangan pemungutan penerimaan negara mayoritas berada di lingkup pemerintah pusat terkait dengan obyek penerimaan, mobilitas sumber penerimaan, efisiensi pemungutan dan perlunya kekuatan politik dalam melakukan pemungutan sehingga memunculkan konsekuensi kepada Pemerintah Pusat untuk memberi bagian penerimaan tersebut kepada Pemerintah Daerah.

Murniasih, \& Mulyadi (2011, hal. 58) menyebutkan bahwa kebijakan pemberian transfer ke daerah oleh Pemerintah Pusat dalam bingkai desentralisasi fiskal di Indonesia dilakukan untuk mengurangi adanya ketidakseimbangan fiskal (fiscal imbalance) baik berupa ketidakseimbangan antara Pemerintah Pusat dan Pemerintah Daerah (vertical fiscal imbalance) maupun ketidakseimbangan antar Pemerintah Daerah (horizontal fiscal imbalance). Terkait ketidakseimbangan antara pemerintah pusat dan pemerintah daerah, Shen, Jin, \& Zhou (2006) dalam Rozani (2017, hal. 3) mencontohkan dalam konteks desentralisasi fiskal di Cina tahun 2003 terjadi vertical fiscal imbalance dimana Pemerintah Pusat menguasai penerimaan yang jauh lebih besar dibandingkan tiga level pemerintahan di daerah, tapi dengan beban pengeluaran yang hampir sama dengan beban pengeluaran pemerintah daerahnya. Dalam beberapa kasus, adanya ketimpangan antara Pemerintah Pusat dengan Pemerintah Daerah terutama dari sisi keuangan dapat memicu timbulnya disintegrasi dan perpecahan.

Secara umum, skema dana transfer dapat dilakukan dalam dua bentuk yaitu dengan syarat (conditional grant) dan tanpa syarat (unconditional grant). Dana transfer dengan syarat merupakan bantuan Pemerintah Pusat kepada daerah untuk penyediaan layanan atau jasa-jasa publik yang sudah ditentukan oleh Pemerintah Pusat sedangkan transfer tanpa syarat merupakan bentuk transfer Pemerintah Pusat ke daerah tanpa disertai ikatan atau syarat tertentu. 
Gambar 1. Jenis Dana Transfer

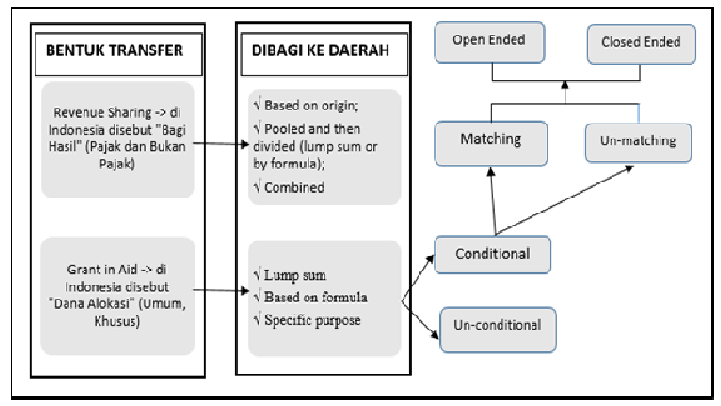

(Sumber: Rozani, 2017)

\subsection{Kemiskinan}

Suryawati (2005, hal. 122) menyebutkan bahwa dalam arti harfiahnya, kemiskinan dipahami sebagai keadaan kekurangan uang dan barang untuk menjamin kelangsungan hidup sedangkan dalam arti yang lebih luas, kemiskinan merupakan suatu fenomena yang bersifat multi dimensional. Suliswanto (2010, hal. 358) mendefinisikan Kemiskinan sebagai suatu standar tingkat hidup yang rendah yang ditandai dengan adanya suatu kekurangan pada tingkat materi dibandingkan dengan tingkat standar hidup yang berlaku umum pada suatu lingkungan masyarakat.

Chambers dalam Suryawati (2005, hal. 122) mengatakan bahwa kemiskinan adalah suatu konsep terintegrasi yang berhubungan dengan lima dimensi, yaitu pertama, kemiskinan (proper); kedua, ketidakberdayaan (powerless); ketiga, kerentanan menghadapi situasi darurat (state of emergency); keempat, ketergantungan (dependence) dan kelima, keterasingan (isolation).

Secara konsep menurut Suryawati (2005, hal. 122), kemiskinan dapat dibagi dalam empat jenis yaitu pertama, kemiskinan absolut yaitu bila pendapatannya di bawah garis kemiskinan atau tidak cukup untuk memenuhi kebutuhan dasar seperti pangan, sandang, kesehatan, perumahan, dan pendidikan; kedua, kemiskinan relatif yaitu kondisi miskin karena pengaruh kebijakan pembangunan yang belum menjangkau seluruh masyarakat sehingga menyebabkan ketimpangan pada pendapatan; ketiga, kemiskinan kultural yaitu mengacu pada persoalan sikap seseorang atau masyarakat yang disebabkan oleh faktor budaya dan keempat, kemiskinan struktural yaitu situasi miskin yang disebabkan karena rendahnya akses terhadap sumber daya yang terjadi dalam suatu sistem sosial budaya dan sosial politik yang tidak mendukung pembebasan kemiskinan, tetapi seringkali menyebabkan suburnya kemiskinan. Berbagai kondisi yang menyebabkan seseorang sulit untuk lepas dari jerat kemiskinan akan menyebabkan kemiskinan menjadi permanen dan berlaku turun-temurun. Hal tersebut disebut Chambers dengan istilah perangkap kemiskinan (poverty trap).
Gambar 2. Perangkap Kemiskinan

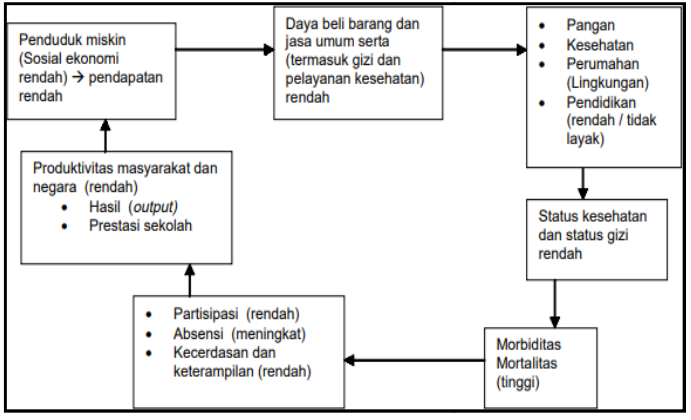

(Sumber: Chambers dalam Suryawati, 2005)

Untuk mengukur kemiskinan, BPS menggunakan konsep kemampuan memenuhi kebutuhan dasar (basic needs approach). Dengan pendekatan ini, kemiskinan dipandang sebagai ketidakmampuan dari sisi ekonomi untuk memenuhi kebutuhan dasar makanan dan bukan makanan yang diukur dari sisi pengeluaran.

\subsection{Dana Desa}

Penyaluran Dana Desa mulai diberlakukan pada tahun 2015 sebagai amanah dari UndangUndang Nomor 6 Tahun 2014 tentang Desa. Disahkannya Undang-undang Nomor 6 Tahun 2014 memperkenalkan Dana Desa sebagai Dana Transfer dari Pemerintah ke Desa melalui Pemerintah Kabupaten/Kota. Dana Desa mulai dialokasikan pada Tahun Anggaran 2015 dengan formula alokasi yang ditetapkan dalam Peraturan Pemerintah.

Kementerian Keuangan (2017, hal. 7) menyebutkan bahwa penyaluran Dana Desa mempunyai 5 tujuan yaitu pertama, meningkatkan pelayanan publik di desa; kedua, mengentaskan kemiskinan; ketiga, memajukan perekonomian desa; keempat, mengatasi kesenjangan pembangunan antar desa dan kelima, memperkuat masyarakat desa sebagai subjek pembangunan. Dengan demikian salah satu tujuan penyaluran Dana Desa adalah untuk mengurangi tingkat kemiskinan.

Dana Desa diberikan dalam rangka mendukung pelaksanaan tugas dan fungsi desa dalam penyelenggaraan pemerintahan dan pembangunan desa dalam segala aspeknya sesuai dengan kewenangan yang dimiliki, Berdasarkan Undang-undang Nomor 6 Tahun 2014 pemerintah mengalokasikan Dana Desa setiap tahun dalam APBN yang diberikan kepada setiap desa sebagai salah satu sumber pendapatan desa.

Dalam Peraturan Menteri Keuangan (PMK) Nomor 193/PMK.07/2018 tentang Pengelolaan Dana Desa, Dana Desa dialokasikan secara merata dan berkeadilan berdasarkan tiga kriteria yaitu alokasi dasar, alokasi afirmasi, dan alokasi formula. Pagu Alokasi Dasar dihitung sebesar 72\% (tujuh puluh dua persen) dari anggaran Dana Desa dibagi secara merata kepada setiap desa. Pagu Alokasi 
Afirmasi dihitung sebesar 3\% (tiga persen) dari anggaran Dana Desa dibagi secara proporsional kepada desa tertinggal dan desa sangat tertinggal yang mempunyai jumlah penduduk miskin tinggi. Pagu Alokasi Formula dihitung sebesar 25\% (dua puluh lima persen) dari anggaran Dana Desa dibagi berdasarkan jumlah penduduk desa (bobot 10\%), angka penduduk miskin desa (bobot $50 \%$ ), luas wilayah desa (bobot 15\%) dan tingkat kesulitan geografis desa (bobot 25\%).

\subsection{Alokasi Dana Desa (ADD)}

Dalam Peraturan Menteri Dalam Negeri Nomor 37 tahun 2007 Tentang Pedoman Pengelolaan Keuangan Desa Pasal 18, Alokasi Dana Desa merupakan dana yang berasal dari APBD Kabupaten/Kota yang bersumber dari Dana Perimbangan Keuangan Pusat dan Daerah yang diterima oleh Pemerintah Kabupaten/Kota untuk desa paling sedikit 10\%. Penggunaan Alokasi Dana Desa antara lain 30\% dipergunakan untuk belanja operasional aparatur desa dan $70 \%$ digunakan untuk pembangunan fisik dan pemberdayaan masyarakat seperti penyertaan modal usaha masyarakat melalui BUMDesa, biaya untuk pengadaan ketahanan pangan dan perbaikan lingkungan dan pemukiman (Nurcholis, 2011, hal. 88-89).

Kriteria yang dipergunakan dalam perhitungan Alokasi Dana Desa adalah pertama, azas merata yaitu besarnya bagian Alokasi Dana Desa yang sama untuk setiap desa atau disebut Alokasi Dana Desa Minimal (ADDM); kedua, azas adil yaitu besarnya bagian Alokasi Dana Desa berdasarkan Nilai Bobot Desa (BDx) yang dihitung dengan rumus dan variabel tertentu, (misalnya kemiskinan, keterjangkauan, pendidikan dasar, kesehatan dan lain-lain), atau disebut Alokasi Dana Desa Proporsional (ADDP); ketiga, besarnya persentase perbandingan antara azas merata dan adil adalah besarnya ADDM adalah 60\% dari jumlah Alokasi Dana Desa dan besarnya ADDP adalah 40\% dari jumlah Alokasi Dana Desa.

\subsection{Produk Domestik Regional Bruto (PDRB)}

Kuznets dalam Todaro (2000, hal. 144) mendefinisikan pertumbuhan ekonomi sebagai kenaikan kapasitas dalam jangka panjang suatu negara dalam menyediakan berbagai barang kepada penduduknya. Kuznets dalam Todaro (2000, hal. 144) juga menyebutkan bahwa pertumbuhan ekonomi dicapai oleh tiga faktor yaitu pertama, peningkatan persediaan barang yang terus-menerus; kedua, perkembangan teknologi; dan ketiga, penggunaan teknologi secara efektif dan efisien. Pertumbuhan ekonomi menjadi hal yang penting dalam satu negara karena dapat melihat apakah negara tersebut telah berhasil memajukan berbagai aspek kehidupan atau tidak.
Suliswanto (2010, hal. 359) menyebutkan bahwa pertumbuhan ekonomi berkaitan dengan kenaikan produksi atau pendapatan per kapita suatu negara sehingga erat kaitannya dengan Produk Domestik Bruto (PDB). Dalam lingkup daerah, pertumbuhan ekonomi suatu daerah diukur dengan nilai Produk Domestik Regional Bruto (PDRB) yang merupakan total nilai barang dan jasa yang diproduksi di wilayah atau regional tertentu dan dalam kurun waktu tertentu biasanya satu tahun. Tingginya tingkat pertumbuhan ekonomi yang ditunjukkan dengan tingginya nilai PDRB menunjukkan bahwa daerah tersebut mengalami kemajuan dalam perekonomian.

PDRB menurut Badan Pusat Statistik didefinisikan sebagai jumlah nilai tambah yang dihasilkan oleh seluruh unit usaha dalam suatu wilayah atau merupakan jumlah seluruh nilai barang dan jasa akhir yang dihasilkan oleh seluruh unit ekonomi di suatu wilayah.

\subsection{Belanja Modal}

Menurut Standar Akuntansi Pemerintah (SAP), Belanja Modal merupakan pengeluaran yang dilakukan dalam rangka pembentukan modal yang sifatnya menambah aset tetap/inventaris dengan manfaat lebih dari satu periode. Dalam Peraturan Menteri Keuangan Nomor 101/PMK.02/2011 tentang Klasifikasi Anggaran disebutkan pengertian belanja modal adalah pengeluaran untuk pembayaran perolehan aset dan/atau menambah nilai aset tetap/aset lainnya yang memberi manfaat lebih dari satu periode akuntansi dan melebihi batas minimal kapitalisasi aset tetap/aset lainnya yang ditetapkan pemerintah. Dalam pembukuan nilai perolehan aset dihitung semua pendanaan yang dibutuhkan hingga aset tersebut tersedia dan siap untuk digunakan termasuk biaya operasional dalam rangka pengadaan aset berkenaan.

Mustaqimah, Hartoyo \& Fahmi (2018, hal. 2) menyebutkan bahwa dari beberapa hasil penelitian menunjukkan bahwa pengeluaran di sektor publik termasuk belanja modal sangat bermanfaat untuk mengurangi jumlah penduduk miskin. Susilowati \& Hadi (2017, hal. 523) dalam penelitian lingkup Kabupaten/Kota di Jawa Timur juga menyimpulkan bahwa belanja modal berpengaruh dalam mengurangi kemiskinan di Kabupaten/Kota di Jawa Timur.

Melalui arah belanja modal yang digunakan untuk pembangunan fisik, maka investasi belanja modal tersebut diharapkan dapat mendorong peningkatan kualitas pelayanan publik dan mendorong pertumbuhan ekonomi. Selanjutnya, adanya pertumbuhan ekonomi diharapkan mampu mengurangi tingkat kemiskinan. 


\subsection{Penelitian Sebelumnya}

Terdapat berbagai penelitian terdahulu yang membahas pengaruh Dana Desa, Alokasi Dana Desa, PDRB dan belanja modal terhadap kemiskinan. Terkait dengan pengaruh Dana Desa, Aghnia (2018, hal. 4-5) melakukan penelitian untuk melihat bagaimana pengaruh kinerja Dana Desa yang sudah berjalan selama 3 tahun dalam kurun waktu 2015-2017 untuk mengentaskan kemiskinan di 33 Provinsi di Indonesia dalam metode data panel. Penelitian ini menarik kesimpulan bahwa Dana Desa memiliki pengaruh terhadap pengentasan Kemiskinan di Indonesia. Dalam penelitian ini, Aghnia (2018, hal. 5) menggunakan variabel bebas meliputi Dana Desa, Pertumbuhan Ekonomi, Indeks Gini, Tingkat Pengangguran Terbuka, dan Indeks Pembangunan Manusia.

Terkait Alokasi Dana Desa, Dewi, \& Irama (2018, hal. 99-100) dalam tiga penelitian yang berbeda dalam lingkup Provinsi Sumatera Utara menarik kesimpulan bahwa Alokasi Dana Desa memiliki pengaruh terhadap kemiskinan di Provinsi Sumatera Utara. Pada penelitian pertama Dewi, \& Irama (2018, hal. 99-100) meneliti pengaruh Alokasi Dana Desa terhadap belanja desa dan kemiskinan dengan kesimpulan Alokasi Dana Desa berpengaruh secara langsung terhadap kemiskinan. Pada penelitian kedua, Dewi, \& Irama (2018, hal. 17) meneliti pengaruh Alokasi Dana Desa terhadap Kemiskinan dengan kesimpulan Alokasi Dana Desa memiliki pengaruh terhadap kemiskinan di Provinsi Sumatera Utara. Sedangkan pada penelitian ketiga, Dewi, \& Irama (2018, hal. 57) meneliti pengaruh Pendapatan Desa dan Alokasi Desa terhadap belanja desa dan kemiskinan dengan kesimpulan Pendapatan Desa dan Alokasi Dana Desa mempunyai pengaruh langsung terhadap Kemiskinan. Azwardi, \& Sukanto (2014, hal. 38-39) yang meneliti pengaruh Alokasi Dana Desa terhadap kemiskinan, juga menyimpulkan bahwa Alokasi Dana Desa berpengaruh negatif terhadap kemiskinan di Provinsi Sumatera Selatan.

Pengaruh variabel Dana Desa dan Alokasi Dana Desa terhadap Kemiskinan yang diteliti secara bersama-sama dilakukan oleh Susilowati \& Hadi (2017, hal. 516) dan Lalira, Nakoko, \& Rorong (2018, hal. 66). Susilowati \& Hadi (2017, hal. 523524) yang meneliti pengaruh Dana Desa, Alokasi Dana Desa, Belanja Modal dan PDRB terhadap kemiskinan, menyimpulkan bahwa variabel Alokasi Dana Desa, Belanja Modal dan PDRB memiliki pengaruh terhadap turunnya tingkat Kemiskinan di Provinsi Jawa Timur. Lalira, Nakoko \& Rorong (2018, hal. 71) meneliti pengaruh Dana Desa dan Alokasi Dana Desa terhadap Tingkat Kemiskinan dengan menarik kesimpulan penelitian bahwa Dana Desa dan Alokasi Dana Desa tidak berpengaruh secara statistik terhadap tingkat
Kemiskinan di Kecamatan Gemeh Kepulauan Talaud.

Terkait dengan pengaruh PDRB terhadap Kemiskinan, terdapat penelitian yang dilakukan oleh (2016, hal. 552) dan Suliswanto (2010, hal. 360). Dama, Lapian, \& Sumual (2016, hal. 557-558) meneliti pengaruh PDRB terhadap jumlah tingkat kemiskinan dan menyimpulkan bahwa PDRB berpengaruh negatif terhadap tingkat kemiskinan di Kota Manado. Sedangkan Suliswanto (2010, hal. 364) meneliti pengaruh PDRB dan IPM terhadap Kemiskinan dengan hasil penelitian menunjukkan PDRB dan IPM berpengaruh negatif terhadap Kemiskinan.

Penelitian yang menganalisis pengaruh Belanja Modal terhadap Kemiskinan antara lain dilakukan oleh Widianto, Sedyautami, \& Nurmansyah (2016, hal. 171) dan Susilowati, \& Hadi (2017, hal. 516). Hasil penelitian Widianto, Sedyautami, \& Nurmansyah (2016, hal. 174) dan Susilowati, \& Hadi (2017, hal. 523) menunjukkan hasil penelitian yang sama di mana belanja modal berpengaruh negatif terhadap kemiskinan.

\subsection{Kerangka Penelitian}

Mengacu pada latar belakang serta tujuan penelitian, secara skematis kerangka penelitian dapat dilihat pada gambar berikut:

Gambar 3. Kerangka Penelitian

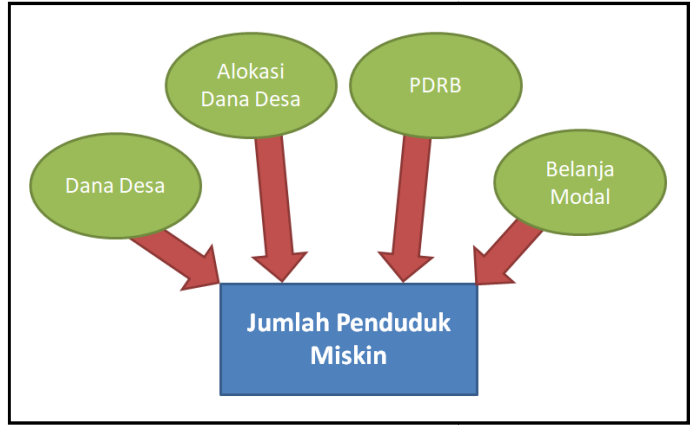

(Sumber: ilustrasi peneliti)

\subsection{Hipotesis Penelitian}

Penelitian ini dilakukan dengan pengembangan hipotesis secara umum diduga Dana Desa, Alokasi Dana Desa, Produk Domestik Regional Bruto (PDRB) dan Belanja Modal secara bersama-sama memiliki pengaruh terhadap Kemiskinan dengan hipotesis secara parsialnya sebagai berikut:

H1: Diduga Dana Desa berpengaruh negatif terhadap Kemiskinan.

H2 : Diduga Alokasi Dana Desa berpengaruh negatif terhadap Kemiskinan.

H3 : Diduga Produk Domestik Regional Bruto (PDRB) berpengaruh negatif terhadap Dama, Lapian, \& Sumual Kemiskinan.

H4 : Diduga Belanja Modal APBD berpengaruh negatif terhadap Kemiskinan. 


\section{METODE PENELITIAN}

\subsection{Jenis Penelitian}

Jenis penelitian ini adalah campuran penelitian kuantitatif dan kualitatif. Penelitian kuantitatif dilakukan dengan menggunakan sumber data sekunder yang berguna untuk pengembangan model matematis dan pengujian hipotesis sehingga dapat diperoleh kesimpulan penelitian. Selain itu, sebagai bahan analisis dan penyusunan rekomendasi kebijakan dilakukan penelitian kualitatif dalam bentuk wawancara mendalam (in-depth interview) yang dilakukan kepada dua orang narasumber yang berasal dari Kementerian Keuangan yaitu unsur dari Badan Kebijakan Fiskal (BKF) dan unsur Direktorat Jenderal Perimbangan Keuangan (DJPK).

\subsection{Jenis dan Sumber Data}

Jenis data sekunder yang digunakan dalam penelitian adalah meliputi data Dana Desa, Alokasi Dana Desa, PDRB dan Belanja Modal serta Jumlah Penduduk Miskin Kabupaten/Kota dari tahun 2015 sampai dengan tahun 2017 untuk seluruh provinsi di Indonesia (kecuali Provinsi DKI Jakarta). Data Dana Desa, Alokasi Dana Desa, dan Belanja Modal APBD Kabupaten/Kota diperoleh dari Ditjen Perimbangan Keuangan sedangkan untuk data PDRB dan data Jumlah Penduduk Miskin diperoleh dari Badan Pusat Statistik (BPS).

Sedangkan untuk data kualitatif berupa wawancara mendalam yang dilakukan penulis kepada narasumber yang berasal dari Kementerian Keuangan yaitu Pejabat Struktural Eselon IV yang menangani Dana Desa pada Direktorat Jenderal Perimbangan Keuangan (Narasumber I) dan Wakil Ketua Tim Kajian Dana Desa Badan Kebijakan Fiskal (Narasumber II).

\subsection{Model Penelitian}

Variabel bebas yang digunakan dalam penelitian ini adalah Dana Desa, Alokasi Dana Desa (ADD), PDRB dan Belanja Modal (BM) sedangkan sebagai variabel terikat adalah Jumlah Penduduk Miskin dengan model persamaan sebagai berikut:

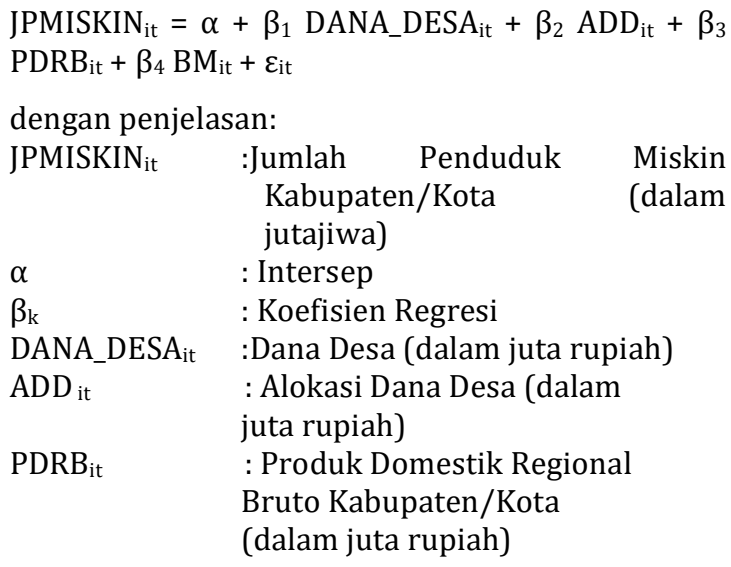
$\mathrm{BM}_{\mathrm{it}}$
: Belanja Modal Kabupaten/
Kota (dalam juta rupiah)
i $: 1,2, \ldots, 433$
t $\quad$ : tahun 2015-2017

\subsection{Definisi Operasional Variabel}

Dana Desa adalah dana APBN yang diperuntukkan bagi desa yang ditransfer melalui APBD kabupaten/kota dan diprioritaskan untuk pelaksanaan pembangunan dan pemberdayaan masyarakat desa (Kementerian Keuangan, 2018).

Alokasi Dana Desa adalah bagian dari dana perimbangan yang diterima kabupaten/kota paling sedikit $10 \%$ (sepuluh perseratus) dalam anggaran pendapatan dan belanja daerah setelah dikurangi dana alokasi khusus (Undang-Undang Nomor 6 Tahun 2014 Tentang Desa).

Produk Domestik Regional Bruto (PDRB) adalah jumlah nilai tambah yang dihasilkan oleh seluruh unit usaha dalam suatu wilayah, atau merupakan jumlah seluruh nilai barang dan jasa akhir yang dihasilkan oleh seluruh unit ekonomi di suatu wilayah. Produk Domestik Regional Bruto atas dasar harga berlaku menggambarkan nilai tambah barang dan jasa yang dihitung menggunakan harga pada setiap tahun, sedang Produk Domestik Regional Bruto atas dasar harga konstan menunjukkan nilai tambah barang dan jasa yang dihitung menggunakan harga pada tahun tertentu (Badan Pusat Statistik, 2018).

Belanja Modal APBD merupakan pengeluaran yang dilakukan dalam rangka pembentukan modal yang sifatnya menambah aset tetap/inventaris yang memberikan manfaat lebih dari satu periode yang dananya berasal dari APBD (Standar Akuntansi Pemerintah, 2017).

Kemiskinan yaitu Jumlah Penduduk Miskin Kabupaten/Kota.

\subsection{Metode Analisis Data}

Metode penelitian yang digunakan dalam penelitian ini adalah analisis regresi data panel dan wawancara mendalam(in-depth interview). Analisis regresi data panel digunakan untuk mengetahui pengaruh Dana Desa, Alokasi Dana Desa, PDRB dan Belanja Modal APBD terhadap Kemiskinan di Indonesia. Penulis juga melakukan wawancara mendalam (in-depth interview) terhadap stakeholders terkait. Hasil analisis wawancara mendalam (in-depth interview) digunakan penulis sebagai bahan analisis dan menyusun rekomendasi. 


\subsubsection{Regresi Data Panel}

3.5.1.1 Data Panel

Data panel merupakan gabungan antara cross section dan time series. Data cross section adalah data yang dikumpulkan dalam satu waktu terhadap banyak individu. Sedangkan data time series adalah data yang dikumpulkan dari waktu ke waktu terhadap suatu individu.

Regresi data panel di bagi menjadi tiga, yaitu Common Effect Model (CEM), Fixed Effect Model (FEM), dan Random Effect Model (REM). Untuk mengetahui model mana yang akan dipilih, maka dilakukan pengujian kesesuaian model.

\subsubsection{Pengujian Kesesuaian Model}

Pengujian kesesuaian model dilakukan dengan menggunakan uji formal yaitu Uji Chow, Uji Hausmann, serta Uji Breusch-Pagan Lagrange Multiplier (BP-LM). Uji Chow digunakan untuk menentukan antara Common Effect Model atau Fixed Effect Model yang terbaik. Lalu Uji Hausmann digunakan untuk menentukan apakah Fixed Effect Model atau Random Effect Model yang terbaik. Sedangkan uji BP-LM digunakan untuk menentukan apakah Random Effect Model atau Common Effect Model yang terbaik digunakan.

Setelah menentukan dan memilih model terbaik, selanjutnya dilakukan pengujian keberartian model (Goodness of Fit). Pengujian ini meliputi bagaimana variabel bebas dalam memengaruhi variabel terikat baik secara simultan menggunakan uji F maupun secara parsial menggunakan uji t. Selain itu, pengujian ini juga melihat seberapa besar variabel bebas yang digunakan dalam model terpilih mampu menjelaskan variabel terikat dalam model menggunakan tingkat $R$-square. Setelah dilakukan pengujian keberartian model, maka selanjutnya model tersebut diinterpretasikan.

\subsubsection{Wawancara Mendalam}

Wawancara mendalam (in-depth interview) macam ini dilakukan dengan informan kunci (key informant) dan subyek penelitian pada umumnya. Informan kunci adalah orang-orang yang karena pengetahuannya luas dan mendalam tentang komunitasnya (atau orang luar yang lama bekerja dengan suatu komunitas) dapat memberikan data yang berharga. Satu teknik yang juga amat berguna untuk memilih informan kunci adalah pengumpulan riwayat hidup (Musianto, 2002, hal. 134). Wawancara mendalam (in-depth interview) dalam penelitian ini dilakukan kepada dua orang narasumber yang berasal dari Kementerian Keuangan yaitu unsur dari Badan Kebijakan Fiskal (BKF) dan unsur Direktorat Jenderal Perimbangan Keuangan (DJPK).

\section{PEMBAHASAN}

\subsection{Deskripsi Data Penelitian}

\subsubsection{Jumlah Penduduk Miskin}

Kemiskinan merupakan masalah multidimensi bagi setiap negara termasuk Indonesia. Kemiskinan yang tinggi mengindikasikan belum tercapainya kesejahteraan masyarakat di suatu negara. Sementara itu, berdasarkan persentase penduduk miskin di Indonesia pada dasarnya secara umum penduduk miskin di Indonesia mengalami penurunan dari tahun ke tahun. Berdasarkan data Badan Pusat Statistik (BPS), jumlah penduduk miskin cenderung mengalami stagnasi dari tahun 2012 sampai dengan tahun 2014 dan terjadi kenaikan pada tahun 2015. Setelah tahun 2015, jumlah penduduk miskin kembali cenderung mengalami penurunan sampai dengan tahun 2017. Dalam empat tahun terakhir, persentase penduduk miskin turun menjadi sebesar 10,12 persen.

Gambar 4. Persentase Kemiskinan di Indonesia Semester 2 Tahun 2012-2017

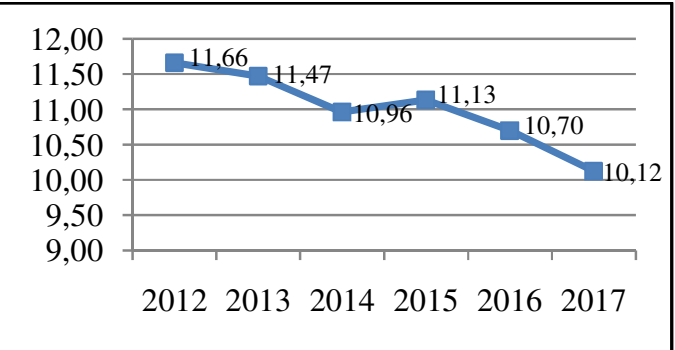

(Sumber: BPS, 2019)

Dari seluruh jumlah penduduk miskin di Indonesia, jumlah tertinggi terpusat di wilayah Jawa, di mana pada tahun 2018 wilayah Jawa memiliki persentase dari total penduduk miskin wilayah secara keseluruhan sebesar 51,71 persen (kecuali Provinsi DKI Jakarta). Hal tersebut disebabkan karena penduduk wilayah Jawa juga lebih besar dari 50 persen dari total penduduk. Sementara itu, wilayah Sumatera memiliki persentase penduduk miskin terhadap total penduduk miskin wilayah sebesar 22,79 persen; Bali dan Nusa Tenggara sebesar 7,86 persen; Kalimantan sebesar 3,77 persen; Sulawesi sebesar 8,05 persen; serta Maluku dan Papua sebesar 5,81 persen. 
Tabel 2. Jumlah Penduduk Miskin dan Persentase Terhadap Total Penduduk Miskin Wilayah di Indonesia Semester 2 Tahun 2017

\begin{tabular}{lrc}
\hline Wilayah & $\begin{array}{c}\text { Jumlah } \\
\text { Penduduk } \\
\text { Miskin } \\
\text { (Ribu Jiwa) }\end{array}$ & $\begin{array}{c}\text { Persentase } \\
\text { Terhadap } \\
\text { Total } \\
\text { Penduduk } \\
\text { Miskin }\end{array}$ \\
\hline Sumatera & $5.969,11$ & 22,79 \\
\hline Jawa & $13.543,33$ & 51,71 \\
\hline $\begin{array}{l}\text { Bali dan Nusa } \\
\text { Tenggara }\end{array}$ & $2.059,34$ & 7,86 \\
\hline Kalimantan & 988,48 & 3,77 \\
\hline Sulawesi & $2.107,63$ & 8,05 \\
\hline Maluku dan & $1.521,98$ & 5,81 \\
Papua & $\mathbf{2 6 . 1 8 9 , 8 7}$ & $\mathbf{1 0 0 , 0 0}$ \\
\hline Total & $(d 1961$
\end{tabular}

(Sumber: BPS, 2019 (diolah tanpa Provinsi DKI Jakarta))

\subsubsection{Dana Desa}

Undang-Undang Nomor 6 Tahun 2014 tentang Desa telah menempatkan desa sebagai ujung tombak pembangunan dan peningkatan kesejahteraan masyarakat. Desa diberikan kewenangan dan sumber dana yang memadai agar dapat mengelola potensi yang dimilikinya guna meningkatkan ekonomi dan kesejahteraan masyarakat salah satunya untuk mengentaskan kemiskinan. Setiap tahun Pemerintah Pusat telah menganggarkan Dana Desa yang cukup besar untuk diberikan kepada desa yang dimulai pada tahun 2015.

Gambar 5. Jumlah Dana Desa Tahun 20152017 (triliun rupiah)

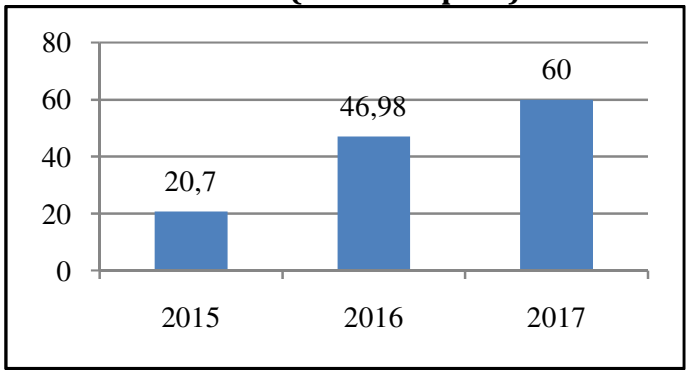

(Sumber: Kementerian Keuangan, 2017)

Pada tahun 2015, Dana Desa dianggarkan sebesar Rp. 20,7 triliun, dengan rata-rata setiap desa mendapatkan alokasi sebesar Rp. 280 juta. Pada tahun 2016, Dana Desa meningkat menjadi Rp. 46,98 triliun dengan rata-rata setiap desa sebesar Rp. 628 juta dan di tahun 2017 kembali meningkat menjadi Rp. 60 triliun dengan rata-rata setiap desa sebesar Rp. 800 juta.

Berdasarkan hasil evaluasi tiga tahun pelaksanaan penyaluran Dana Desa dari Kementerian Keuangan, kebijakan Dana Desa telah berkontribusi dalam menghasilkan sarana/prasarana yang meliputi 95,2 ribu kilometer jalan desa; 914 ribu meter jembatan; 22.616 unit sambungan air bersih; 2.201 unit tambatan perahu; 14.957 unit PAUD; 4.004 unit Polindes; 19.485 unit sumur; 3.106 pasar desa; 103.405 unit drainase dan irigasi; 10.964 unit Posyandu; dan 1.338 unit embung dalam periode 2015-2016 (Kemenkeu, 2017, hal. i). Peningkatan sarana/prasarana tersebut akan membantu menunjang kegiatan sekaligus perekonomian masyarakat.

\subsection{Analisis Regresi Data Panel}

\subsubsection{Pengujian Kesesuian Model}

Dalam melakukan pengujian kesesuaian model, tahap pertama yang dilakukan adalah melakukan Uji Chow, jika model yang terpilih adalah FEM, maka dilanjutkan Uji Hausman dengan kesimpulan berdasarkan pengujian Hausman. Namun, jika model yang terpilih pada Uji Chow adalah CEM, maka dilanjutkan pada pengujian BPLM dengan kesimpulan berdasarkan uji BP-LM tersebut.

Tabel 3. Hasil Pengujian Kesesuaian Model

\begin{tabular}{llll}
\hline Uji & Hipotesis & Prob. & Keputusan \\
\hline Chow & $\mathrm{H}_{0}:$ CEM & 0,000 & FEM \\
Test & $\mathrm{H}_{1}:$ FEM & & \\
\hline Hausman & $\mathrm{H}_{0}:$ REM & 0,000 & FEM \\
Test & $\mathrm{H}_{1}:$ FEM & & \\
\hline
\end{tabular}

(Sumber: data diolah)

Berdasarkan pengujian di atas, keputusan yang diambil pada uji Chow adalah tolak H0 karena $p$-value sebesar 0,000 lebih kecil dari tingkat signifikansi lima persen. Dengan demikian, dilanjutkan pengujian kesesuaian model dengan menggunakan uji Hausman. Berdasarkan Uji Hausman, dapat disimpulkan bahwa model yang tepat digunakan untuk menggambarkan Dana Desa, Alokasi Dana Desa, PDRB dan belanja modal terhadap jumlah penduduk miskin adalah Fixed Effect Model (FEM).

\subsubsection{Hasil Analisis}

Berdasarkan hasil estimasi model, Dana Desa Alokasi Dana Desa, PDRB dan belanja modal terhadap jumlah penduduk miskin dapat digambarkan dalam ringkasan hasil statistik sebagai berikut: 
Tabel 4. Ringkasan statistik hasil estimasi Fixed Effect Model

\begin{tabular}{lrrr}
\hline \multicolumn{1}{c}{ Variabel } & Koefisien & $\begin{array}{c}\text { t- } \\
\text { hitung }\end{array}$ & p-value \\
\hline $\mathrm{C}$ & 65.3270 & 59.2654 & $0,0000^{*}$ \\
\hline DANA_DESA & -0.0166 & -8.0710 & $0.0000^{*}$ \\
\hline ADD & -0.0375 & -2.9462 & $0.0033^{*}$ \\
\hline PDRB & -0.0001 & -2.9895 & $0.0029^{*}$ \\
\hline BM & -0.0011 & -1.5003 & 0.1339 \\
\hline \hline $\mathrm{R}^{2}$ & & & 0.9991 \\
\hline Adjusted R ${ }^{2}$ & & & 0.9987 \\
\hline F-Statistic & & & 2151.7900 \\
\hline Prob(F-Statistic) & & & 0.0000 \\
\hline Durbin-Watson & & & 2.1485 \\
\hline (Sumber: data diolah) & & &
\end{tabular}

Berdasarkan hasil di atas, maka persamaan yang dapat menggambarkan Dana Desa, Alokasi Dana Desa, PDRB dan belanja modal terhadap jumlah penduduk miskin dapat dituliskan sebagai berikut:

$$
\begin{aligned}
& J P \widehat{\text { lsk }} n_{l t}=65,3270-0,0166 \text { Dana_Desa }_{\mathrm{it}}{ }^{*} \\
& -0,0375 \mathrm{ADD}_{\mathrm{it}}{ }^{*}-0,0001 \mathrm{PDRB}_{\mathrm{it}}{ }^{*} \\
& -0,0011 \mathrm{BM}_{\mathrm{it}}
\end{aligned}
$$

Berdasarkan pengujian pengaruh secara simultan melalui uji F-Statistic, dapat disimpulkan bahwa variabel bebas yang digunakan pada persamaan regresi data panel secara bersamasama memiliki pengaruh terhadap Jumlah Penduduk Miskin Kabupaten/Kota di Indonesia. Sementara itu, pengujian secara parsial menunjukkan bahwa dengan tingkat signifikansi lima persen, variabel Dana Desa, ADD dan PDRB memiliki pengaruh negatif terhadap Jumlah Penduduk Miskin. Hal tersebut dapat dilihat dari nilai probabilitas yang lebih kecil dari lima persen. Sementara itu, Belanja Modal tidak memiliki pengaruh secara statistik terhadap Jumlah Penduduk Miskin karena memiliki probabilitas lebih besar dari lima persen.

Koefisien Determinasi dari hasil analisis regresi menunjukkan kemampuan variabel bebas dalam menjelaskan variabel terikat. Koefisien Determinasi ditunjukkan dengan nilai Adjusted $R^{2}$. Dari hasil regresi diperoleh nilai Adjusted $R^{2}$ sebesar 0,9987. Hal ini menunjukkan bahwa 99,87\% variasi dari variabel Jumlah Penduduk Miskin mampu dijelaskan oleh variabel Dana Desa, Alokasi Dana Desa, PDRB dan Belanja Modal sedangkan sisanya dijelaskan oleh variabel lain di luar penelitian.

Untuk menguji apakah dalam model regresi memiliki korelasi antara kesalahan pengganggu pada periode $t$ dengan kesalahan pengganggu pada periode $\mathrm{t}-1$ (sebelumnya), maka dilakukan Uji Autokorelasi menggunakan uji statistik Durbin Watson. Menurut Ghozali (2013, hal. 110), untuk mendeteksi ada atau tidaknya autokorelasi bisa menggunakan Uji Durbin-Watson (DW test). Jika nilai Durbin Watson hitung mendekati angka 2 maka model tersebut terbebas dari asumsi klasik autokorelasi, karena angka 2 pada uji Durbin Watson terletak di daerah non-autocorrelation. Pada tabel di atas, nilai Durbin-Watson memiliki nlai yang mendekati 2 sehingga dapat disimpulkan tidak terjadi masalah autokorelasi.

\section{Pengaruh Dana Desa}

Variabel dana desa memiliki pengaruh negatif sesuai dengan hasil regresi berdasarkan nilai dari koefisien regresi yang bernilai negatif. Hal tersebut menunjukkan bahwa ketika dana desa naik maka jumlah penduduk miskin akan menurun. Hasil tersebut sama dengan hasil penelitian Susilowati \& Hadi (2017, hal. 524) yang menyimpulkan bahwa Dana Desa memiliki pengaruh terhadap turunnya tingkat Kemiskinan di Provinsi Jawa Timur dan penelitian Aghnia (2018, hal. 30-31) yang menyimpulkan bahwa Dana Desa berpengaruh terhadap pengentasan kemiskinan di Indonesia.

Selain itu, pengaruh dana desa terhadap kemiskinan juga sejalan dengan pendapat narasumber terkait pertanyaan pengaruh Dana Desa terhadap Kemiskinan. Narasumber I menyebutkan bahwa Dana Desa mempunyai pengaruh dalam menurunkan kemiskinan dalam kisaran angka 2 juta jiwa dalam kurun waktu 20152018. Hal ini didasarkan pada pernyataan:

"Dengan basis data saja, Pelaksanaan Dana Desa turut memberikan kontribusi positif dalam tiga tujuan utamanya. Pertama, dari segi ketimpangan, rasio gini perdesaan terus menurun lho dari 0,329 pada tahun 2015 menjadi 0,320 pada tahun 2018. Berarti kan dalam tiga tahun rasio gini sudah turun meskipun belum besar. Kedua, jumlah penduduk miskin perdesaan juga turun sekitar 2 juta. Tahun 2015 yang sekitar 17,89 juta jiwa (14,09\%) turun menjadi 15,54 juta jiwa $(12,24 \%)$ pada tahun 2018. Ketiga, pengangguran juga turun. Dari 4,93\% pada tahun 2015 menjadi 4,04\% pada tahun 2018."

Narasumber I kembali memberi penegasan tentang pengaruh Dana Desa dalam menurunkan Kemiskinan berdasarkan pernyataan:

"Data tadi sudah berbicara bahwa Dana Desa punya efek mengurangi Kemiskinan. Ini karena salah satu penggunaan Dana Desa itu untuk program Padat karya tunai (Cash for work) yang merupakan kegiatan pemberdayaan masyarakat desa khususnya yang miskin yang bersifat produktif. Pas program tersebut penggunaan resourcenya mengutamakan pemanfaatan sumber daya, tenaga kerja, dan teknologi lokal untuk memberikan tambahan upah bagi masyarakat desa yang terlibat. Dari tambahan pendapatan itulah mereka jadi meningkat daya belinya sehingga kemiskinan bisa dikurangi. Dari pola ini jugalah diharapkan angka stunting dapat berkurang" 
Ketika dilakukan elaborasi lebih lanjut terkait penelitian empiris yang membuktikan Dana Desa dapat menurunkan Kemiskinan, Narasumber I menyebutkan sudah ada dua penelitian yang membuktikan bahwa Dana Desa dapat mengurangi Kemiskinan berdasarkan pernyataan:

"Sudah ada, contohnya penelitian dari World Bank dan KOMPAK yaitu formula Dana Desa dan kaitannya dengan program penanggulangan kemiskinan dan Dampak Dana Desa terhadap Pertumbuhan Ekonomi dan Pengurangan Kesenjangan. Hasilnya bisa mengurangi kemiskinan meski masih perlu banyak perbaikan"

Pendapat yang sama juga disampaikan oleh Narasumber II yang menyatakan bahwa secara umum memang penyaluran Dana Desa memberi pengaruh positif terhadap kondisi masyarakat desa dengan pernyataan:

"Ada beberapa temuan menarik yang kami temukan. Pertama memang infrastruktur fisik desa berkembang dengan pesat. Jika dibandingkan dengan kelurahan, gap sudah berkurang. Ini kan tidak terlepas dari penggunaan dana desa sebagian besar untuk pembangunan fisik. Lalu kedua, kami juga menemukan BUMDes juga dapat berkembang pesat. Namun secara jumlah output dan kualitas yang dihasilkan masih belum maksimal"

Terkait pengaruh Dana Desa terhadap Kemiskinan, Narasumber II menyebutkan bahwa pengaruh memang ada tapi menurutnya masih minim berdasarkan pernyataan:

"Penelitian BKF-PKN STAN ini tidak secara khusus menjangkau itu. Kami ingin melihat dampak Dana Desa terhadap 3 jenis : pertama kami melihat dampak Dana Desa terhadap BUMDes, yang kedua dampak itu terhadap kesempatan kerja, dan ketiga terhadap infrastruktur itu sendiri. Tapi dengan model pengelolaan yang masih tradisional, kemungkinan dampaknya terhadap Kemiskinan masih kecil".

Ketika dilakukan elaborasi lebih lanjut bagaimana pengelolaan Dana Desa sehingga dianggap masih belum maksimal, Narasumber II memberikan pernyataan:

"Yang kami temukan di lapangan secara umum ada diskresi Kepala Desa 70\% digunakan untuk pembangunan fisik dan 30\% digunakan untuk keperluan lain seperti Badan Usaha Milik Desa (BUMDes) dan Administrasi Desa"

"BUMDes perlu suntikan modal. Kondisi kualitas SDM nya juga masih minim. Misalnya seperti ini, ada BUMDes yang pengelolaannya masih tradisional. Mereka hanya membuka warung kelontong. Ini kan tentu saja tidak akan maksimal. Ini masih ditambah dengan kondisi BUMDes mengakomodir hubungan istimewa. Pihak-pihak yang punya hubungan tersebut masih sering mendapat prioritas tertentu. BUMDes juga perlu membuka lapangan kerja yang masih terbatas. Tapi ini menurut saya bisa dimaklumi karena porsi untuk BUMDes kan masih lebih kecil dibanding sektor fisik. Kedepan menurut saya perlu diatur regulasinya sebaiknya berapa untuk SDM berapa untuk infrastruktur."

Dengan demikian berdasarkan pernyataan dari dua orang narasumber tersebut dapat disimpulkan bahwa penyaluran Dana Desa dapat berpengaruh dalam menurunkan jumlah kemiskinan meskipun ada catatan bahwa perannya belum maksimal dan masih perlu ditingkatkan lagi. Hasil ini tentu saja sejalan dengan hasil regresi yang menunjukkan bahwa Dana Desa berpengaruh negatif terhadap kemiskinan.

Terkait dengan perbaikan yang perlu dilakukan dalam penyaluran Dana Desa, masingmasing narasumber memberikan berbagai masukan. Narasumber I misalnya menyampaikan masukan terkait perlunya peningkatan inovasi penggunaan Dana Desa berdasarkan pernyataan:

"Perlunya penajaman penggunaan dana desa, biar tidak monoton penggunaannya. Terutama melalui prioritas belanja sektor tertentu, salah satunya adalah dengan pengembangan potensi ekonomi lokal. Selain itu menurut saya juga perlu penajaman fungsi BUMDes agar mampu menjadi penopang ekonomi desa".

Narasumber I juga merekomendasikan penyempurnaan formulasi Dana Desa berdasarkan pernyataan:

"Pola/formulasi pengalokasian Dana Desa hendaknya selalu disempurnakan agar desa semakin berkembang, sehingga ketergantungan atas Dana Desa lambat laun akan berkurang".

"Dalam beberapa tahun terakhir, Kemenkeu telah melakukan perubahan kebijakan, terutama dalam hal pengalokasian Dana Desa. Reformulasi Pengalokasian Dana Desa ditujukan untuk mengurangi kemiskinan. Saya contohkan tahun 2019 ini misalnya, telah dilakukan reformulasi pengalokasian Dana Desa. Proporsi Alokasi Dasar dikurangi. Alokasi ini kan yang dibagi sama rata kepada setiap Desa. Lalu proporsi Alokasi Formula ditambah dari semula 20\% menjadi 25\%. Selain itu juga diberikan Alokasi Afirmasi kepada Desa Tertinggal dan Desa Sangat Tertinggal dengan jumlah penduduk miskin tinggi".

Selain itu, terkait pengawasan penggunaan Dana Desa menurut Narasumber I juga masih perlu ditingkatkan sinerginya berdasarkan pernyataan:

"Memang berbahaya jika tidak diawasi secara ketat. Itulah mengapa dibuat pengawasan yang terintegrasi. Siapa saja yang terlibat? Ada aparat pengawas fungsional di daerah, ada pembinaan kepada desa oleh Pemda, mengoptimalkan peran 
organisasi perangkat daerah kabupaten/kota dan kecamatan dalam melaksanakan pendampingan teknis, pembentukan Sekretariat Pengawalan Dana Desa di kabupaten/kota agar tidak ada penyimpangan. Secara lebih makro pun juga ada. POLRI, KPK, Kejaksaan, dan BPKP juga digandeng melalui MoU untuk melakukan pengawasan terhadap penggunaan dana desa. Selain itu ada kerjasama dengan Perguruan Tinggi, Organisasi Kemasyarakatan, dan LSM yang tergabung dalam POKJA masyarakat sipil dalam melakukan monitoring dan pengawasan penggunaan dana desa".

Sedangkan Narasumber II juga menyampaikan rekomendasi untuk perbaikan penyaluran Dana Desa terkait formulasi penganggaran Dana Desa, penguatan alokasi BUMDes dari Dana Desa dan peningkatan inovasi BUMDes berdasarkan pernyataan:

"Pertama, merubah formula dengan memperhatikan jumlah populasi, luas wilayah dan apa tujuan utama dari Dana Desa. Kedua, bagaimana dari BUMDes yang sudah terbentuk bisa ditingkatkan efektivitasnya. Antara lain bisa dengan meningkatkan partisipasi masyarakat dan kerjasama dengan swasta. Ketiga, BUMDes bisa terus berinovasi dan melibatkan masyarakat desa dalam pemasarannya"

"Terutama terkait Dana Desa per kapita yang tidak seimbang antara pulau Jawa yang padat penduduknya dengan luar Jawa yang sedikit penduduknya. Akibatnya kalau dihitung per kapita, jumlah Dana Desa yang diterima per penduduk di luar jawa dua kali lipat di Jawa. Sumatera misalnya dua kali lipat jawa, sedangkan lainnya bisa empat kali lipat Jawa. Jawa kalau dihitung per kepala hanya menerima Dana Desa 100-200 ribu per orang per tahun. Jadi formula perlu diatur, sekarang kan formula flat lebih dominan. Diskresi Kepala Desa akan bagus kalau SDMnya siap. Tapi yang kami temukan SDMnya mayoritas belum siap. Untuk Kepala Desa pun rata-rata dari temuan kami berpendidikan SMA. Jadi sebaiknya diperjelas saja berapa buat SDM berapa buat infrastruktur agar setiap Kepala Desa bisa punya juknis yang tepat".

Selain itu Narasumber II juga menekankan pentingnya pengawasan dari pihak-pihak terkait agar penggunaan Dana Desa tidak terjadi redundant (duplikasi) dengan dana lainnya sehingga rentan dengan terjadinya double accounting berdasarkan pernyataan:

"Memang kami melihat ada dana lain. Overlapping bisa terjadi walaupun kami tidak bisa melihatnya secara empiris. Misal PNPM bagaimana? Overlapping tidak? Kami mengkhawatirkan ada double accounting. Pengeluarannya PNPM tapi juga dicatat di pengeluaran Dana Desa".
Dengan demikian, berdasarkan pernyataan di atas kedua narasumber bersepakat bahwa minimal terdapat tiga aspek yang dapat terus diperbaiki untuk perbaikan penganggaran dan penyaluran Dana Desa yaitu meliputi aspek penyempurnaan formulasi Dana Desa, aspek penguatan pengawasan penyaluran Dana Desa dan aspek peningkatan inovasi penggunaan Dana Desa.

Terkait aspek penyempurnaan formulasi Dana Desa, porsi Alokasi Dasar ke depan hendaknya dapat semakin dikurangi dan porsi Alokasi Formula dapat semakin diperbesar. Selain itu adanya Alokasi Afirmasi kepada Desa Tertinggal dan Desa Sangat Tertinggal dengan jumlah penduduk miskin tinggi juga dapat terus dipertahankan. Formulasi Dana Desa hendaknya juga memperhatikan nilai per kapitanya dimana wilayah yang padat penduduknya secara riil akan cenderung lebih kecil jumlah Dana Desa yang diterimanya dibandingkan wilayah yang kurang padat penduduknya. Tentu saja hal ini sudah dan dapat terus menjadi perhatian pihak terkait khususnya Kementerian Keuangan dalam melakukan penyempurnaan formulasi penganggaran Dana Desa berikutnya. Selain itu, pengaturan porsi penggunaan Dana Desa juga perlu diatur. Dengan kondisi saat ini porsi pengeluaran untuk sektor fisik yang lebih besar, ke depan perlu diatur agar sektor pemberdayaan masyarakat desa termasuk di dalamnya peningkatan porsi anggaran Dana Desa untuk BUMDes dan peningkatan SDM dapat semakin ditingkatkan. Dengan adanya pengaturan ini setiap Kepala Desa akan memiliki petunjuk teknis yang memadai dalam pengalokasian anggaran Dana Desa sehingga porsi untuk sektor fisik dan sektor pemberdayaan masyarakat dapat lebih seimbang.

Terkait aspek peningkatan inovasi penggunaan Dana Desa, peningkatannya dapat dilakukan dengan melakukan pelatihan secara kontinyu baik dari unsur Pemerintah Pusat maupun Pemerintah Daerah kepada aparatur dan pengelola BUMDes. Selain itu dapat juga dilakukan kerja sama dengan sektor swasta agar perangkat desa dan pengelola BUMDes dapat lebih mampu berinovasi dalam penggunaan Dana Desa.

Terkait aspek pengawasan penggunaan Dana Desa, perlu ditingkatkan sinergi baik dari unsur masyarakat desa, aparat fungsional Pemerintah Daerah, BPKP, maupun BPK sehingga pengawasan dapat berjalan secara efektif dan tidak tumpang tindih. Sinergi tersebut dapat dilakukan dalam bentuk pembagian peran dan obyek pengawasan secara jelas sehingga pengawasan dapat dilakukan secara efektif dan efisien.

\section{Pengaruh Alokasi Dana Desa}

Variabel Alokasi Dana Desa memiliki pengaruh negatif terhadap Jumlah Penduduk Miskin berdasarkan nilai dari koefisien regresi 
yang bernilai negatif. Hal tersebut menunjukkan bahwa ketika Alokasi Dana Desa naik maka jumlah penduduk miskin akan menurun. Hasil tersebut sama dengan hasil penelitian Dewi \& Irama (2018, hal. 57) yang menarik kesimpulan bahwa Alokasi Dana Desa berpengaruh terhadap Kemiskinan di Provinsi Sumatera Utara dan penelitian Azwardi, \& Sukanto (2014, hal. 38-39) yang juga menyimpulkan bahwa ADD berpengaruh negatif terhadap Kemiskinan di Provinsi Sumatera Selatan.

Selain itu, berdasarkan hasil penelitian Prasetyanto (2012, hal. 139) menyimpulkan bahwa penyaluran Alokasi Dana Desa telah memberikan arah yang benar untuk meningkatkan kinerja fiskal dan perekonomian daerah dengan mengurangi jumlah penduduk miskin. Hasil simulasi kebijakan yang dilakukan pada penelitian tersebut menunjukkan bahwa peningkatan penyaluran Alokasi Dana Desa mampu meningkatkan kapasitas fiskal (fiscal capacity) daerah, yaitu antara lain mampu meningkatkan Pendapatan Asli Daerah (PAD) sebagai salah satu tolok ukur kemandirian daerah. Peningkatan penyaluran anggaran Alokasi Dana Desa juga mampu meningkatkan total pengeluaran daerah untuk mendorong peningkatan kebutuhan fiskal (fiscal needs) daerah. Selanjutnya peningkatan penyaluran Alokasi Dana Desa juga mampu meningkatkan pertumbuhan ekonomi dan mampu menurunkan Jumlah Penduduk Miskin di perdesaan.

\section{Pengaruh Produk Domestik Bruto}

Variabel PDRB memiliki pengaruh negatif sesuai dengan hasil regresi berdasarkan nilai dari koefisien regresi yang bernilai negatif. Hal tersebut menunjukkan bahwa ketika PDRB naik atau terjadi kenaikan pada pertumbuhan ekonomi maka jumlah penduduk miskin akan menurun. Hasil tersebut sama dengan hasil penelitian Dama, Lapian, \& Sumual (2016, hal. 557-558) yang menyimpulkan bahwa PDRB berpengaruh negatif terhadap Tingkat Kemiskinan di Kota Manado dan penelitian Suliswanto (2010, hal. 364) yang menyimpulkan bahwa PDRB berpengaruh negatif terhadap kemiskinan.

Pengaruh PDRB terhadap penurunan jumlah penduduk miskin dapat disebabkan karena ketika terjadi peningkatan pada pertumbuhan ekonomi, maka rata-rata pengeluaran perkapita juga akan meningkat. Peningkatan tersebut akan sejalan dengan penurunan kemiskinan (Nanga, 2006, hal. 134).

\section{Pengaruh Belanja Modal}

Berbeda dengan variabel bebas lain, variabel Belanja Modal tidak memiliki pengaruh secara statistik terhadap Jumlah Penduduk Miskin. Hasil tersebut berbeda dengan hasil penelitian Widianto, Sedyautami, \& Nurmansyah (2016, hal. 174) yang menyimpulkan bahwa Belanja Modal berpengaruh negatif terhadap Kemiskinan namun yang perlu digarisbawahi dari penelitian Widianto, Sedyautami, \& Nurmansyah (2016, hal. 174) adalah Belanja Modal yang digunakan berasal dari APBN bukan APBD Kabupaten/Kota sebagaimana dalam penelitian ini.

Belanja Modal dari APBD tidak memiliki pengaruh secara statistik langsung terhadap Kemiskinandikarenakan Belanja Modal memiliki fokus untuk meningkatkan aset daerah. Aset-aset tersebut nantinya dapat meningkatkan perekonomian daerah sehingga Belanja Modal memiliki pengaruh tidak langsung terhadap kemiskinan.

Widianto, Sedyautami, \& Nurmansyah (2016, hal. 174) menyebutkan bahwa belanja modal yang berasal dari APBN dapat berpengaruh negatif terhadap kemiskinan bermakna bahwa berbagai kebijakan dan program pengentasan kemiskinan yang diimplementasikan di daerah semuanya masih merupakan program yang dirumuskan oleh Pemerintah Pusat dan masih adanya ketergantungan dari daerah terhadap pembiayaan implementasi kebijakan/program pengentasan kemiskinan masih ketergantungan kepada Pemerintah Pusat sehingga sebagian besar pembiayaan pengentasan kemiskinan masih dibiayai oleh Pemerintah Pusat. Oleh karena itu, Pemerintah Daerah harus terus berupaya meningkatkan efektivitas alokasi dan penggunaan Belanja Modal dari APBDnya agar mampu bersinergi dengan penyaluran Belanja Modal dari APBN. Sinergi tersebut sangat penting untuk menghindari adanya pemborosan anggaran dan duplikasi kegiatan. Dengan peningkatan efektivitas Belanja Modal APBD dan disertai sinergi yang jelas dengan Belanja Modal APBN tersebut diharapkan realisasi Belanja Modal APBN dan APBD mempunyai multiplier effect yang lebih besar dalam mengurangi kemiskinan di desa.

\section{KESIMPULAN}

\subsection{Kesimpulan}

Berdasarkan hasil analisis dapat disimpulkan sebagai berikut:

1. Model yang tepat digunakan untuk menggambarkan Dana Desa, Alokasi Dana Desa, PDRB, dan belanja modal terhadap jumlah penduduk miskin adalah Fixed Effect Model (FEM).

2. Kebijakan penyaluran Dana Desa, Alokasi Dana Desa, PDRB, dan Belanja Modal secara bersamasama memiliki pengaruh terhadap Jumlah Penduduk Miskin Kabupaten/Kota di Indonesia.

3. Secara parsial, pengaruh dari tiap-tiap variabel adalah sebagai berikut:

a. Penyaluran Dana Desa mampu memberikan pengaruh negatif terhadap Jumlah 
Penduduk Miskin Kabupaten/Kota di Indonesia.

b. Variabel lain yang meliputi Alokasi Dana Desa dan PDRB juga memiliki pengaruh negatif terhadap Jumlah Penduduk Miskin Kabupaten/Kota di Indonesia.

c. Variabel Belanja Modal tidak memiliki pengaruh terhadap Jumlah Penduduk Miskin Kabupaten/Kota di Indonesia.

4. Dari hasil wawancara mendalam, minimal terdapat tiga aspek dari kebijakan Dana Desa yang perlu diperbaiki yaitu meliputi penyempurnaan aspek formulasi, aspek penguatan pengawasan, dan aspek peningkatan inovasi dalam penggunaan Dana Desa.

\subsection{Saran}

Berkaitan dengan hasil pengujian dan kesimpulan tersebut, diberikan rekomendasi sebagai berikut:

1. Perlunya dilakukan penyempurnaan formulasi penganggaran Dana Desa antara lain dengan meningkatkan porsi Alokasi Formula, Alokasi Afirmasi, dan pengaturan porsi penggunaan Dana Desa sehingga alokasi untuk sektor fisik dan sektor pemberdayaan masyarakat desa dapat lebih seimbang.

2. Perlunya peningkatan inovasi dan sinergi baik dari unsur masyarakat desa, aparat fungsional Pemerintah Daerah, BPKP, dan BPK dalam melaksanakan pengawasan penggunaan Dana Desa.

3. Perlunya peningkatan porsi Alokasi Dana Desa dari APBD Pemerintah Daerah sehingga porsi alokasi anggaran yang berasal dari Alokasi Dana Desa untuk sektor pemberdayaan masyarakat desa dapat semakin ditingkatkan.

4. Dengan tidak signifikannya Belanja Modal APBD dalam menurunkan Kemiskinan di desa, kiranya perlu dirumuskan kebijakan pengeluaran Belanja Modal dari dana APBD secara lebih efektif serta menghindari terjadinya redundant (duplikasi) dengan Belanja Modal dari APBN sehingga realisasi Belanja Modal APBN dan APBD tersebut dapat memberikan multiplier effect yang lebih besar dalam menurunkan angka Kemiskinan.

\section{IMPLIKASI DAN KETERBATASAN}

\subsection{Implikasi Penelitian}

Implikasi penelitian ini dari aspek praktis diharapkan dapat memberikan manfaat bagi Kementerian Keuangan c.q. Direktorat Jenderal Perimbangan Keuangan dan Kementerian Desa, Pembangunan Daerah Tertinggal Dan Transmigrasi serta Pemerintah Daerah dalam ranah implementasi kebijakan dan penyaluran Dana
Desa terutama terkait perannya dalam mengatasi kemiskinan di Indonesia.

\subsection{Keterbatasan Penelitian}

Penelitian ini terbatas pada ketersediaan data penelitian tahun 2015 s.d. 2017 dikarenakan data PDRB Kabupaten/Kota tahun 2018 belum tersedia.

\section{REFERENSI}

Aghnia, N. L. (2018). Pengaruh dana desa dalam pengentasan kemiskinan di Indonesia. Skripsi. Bogor: Institut Pertanian Bogor.

Azwardi, \& Sukanto. (2014). Efektifitas alokasi dana desa (add) dan kemiskinan di provinsi Sumatera Selatan. Jurnal Ekonomi Pembangunan, 12(1), 29-41.

Badan Pusat Statistik. (2019). Statistik Indonesia 2019. Jakarta: BPS.

Dama, H. Y., Lapian, A. L. C., \& Sumual, J. I. (2016). Pengaruh produk domestik regional bruto terhadap tingkat kemiskinan di kota Manado (tahun 2005-2014). Jurnal Ilmiah Berkala Efisiensi, 16(3), 549-561.

Davey, K. (1988). Pembiayaan pemerintahan daerah. Jakarta: UI Press.

Dewi, R. S., \& Irama, O. N. (2018). Pengaruh alokasi dana desa terhadap belanja desa dan kemiskinan. Jurnal Kitabah, 2(1), 86-101.

Dewi, R. S., \& Irama, O. N. (2018). Pengaruh alokasi dana: studi kasus di provinsi Sumatera Utara. Jurnal Akuntansi dan Bisnis, 4(2), 11-18.

Dewi, R. S., \& Irama, O. N. (2018). Pengaruh pendapatan desa dan alokasi dana desa terhadap belanja desa dan kemiskinan. Jurnal Riset Akuntansi Multiparadigma (JRAM), 5(2), 50-58.

Ghozali, I. (2013). Aplikasi analisis multivarite dengan spss. Edisi Keempat. Semarang: Badan Penerbit Universitas Diponegoro.

Kementerian Keuangan. (2017). Buku saku dana desa. Jakarta: Kementerian Keuangan.

Lalira, D., Nakoko, A. T., \& Rorong, I. P. F. (2018). Pengaruh dana desa dan alokasi dana desa terhadap tingkat kemiskinan di Kecamatan Gemeh Kabupaten Kepulauan Talaud. Jurnal Berkala Ilmiah Efisiensi, 18(4), 62-72.

Murniasih, E. \& Mulyadi, M. S. (2011). Pengaruh transfer pemerintah pusat terhadap perilaku fiskal pemerintah daerah di provinsi Kalimantan Timur. Jurnal Ekonomi dan Pembangunan Indonesia, 12(1), 56-71.

Musianto, L. S. (2002). Perbedaan pendekatan kuantitatif dengan pendekatan kualitatif dalam 
metode penelitian. Jurnal Manajemen \& Kewirausahaan, 4(2), 123 - 136.

Mustaqimah, K, Hartoyo, S., \& Fahmi, I. (2017). Peran belanja modal pemerintah dan investasi pembangunan manusia dalam mengurangi tingkat kemiskinan di Indonesia. Jurnal Ekonomi dan Kebijakan Pembangunan, 6(2), 1-15.

Nanga, M. (2006). Dampak transfer fiskal terhadap kemiskinan di Indonesia: suatu analisis simulasi kebijakan. Disertasi. Bogor: Institut Pertanian Bogor.

Nurcholis, H. (2011). Pertumbuhan dan penyelenggaraan pemerintahan desa. Jakarta: Erlangga.

Peraturan Menteri Dalam Negeri Nomor 37 tahun 2007 Tentang Pedoman Pengelolaan Keuangan Desa.

Peraturan Menteri Keuangan Nomor 101/PMK.02/2011 tentang Klasifikasi Anggaran.

Peraturan Menteri Keuangan Nomor 193/PMK.07/2018 tentang Pengelolaan Dana Desa.

Prasetyanto, E. (2012). Dampak alokasi dana desa pada era desentralisasi fiskal terhadap perekonomian daerah di Indonesia. Disertasi. Bogor: Institut Pertanian Bogor.

Rinusu, S. M. (2006). Pedoman Propoor and Gender Budgeting. Bandung: Ciba.

Rozani, I. (2017). Transfer dana pemerintah pusat. Bahan ajar pada Universitas Indonesia. Tidak dipublikasikan.

Saputra, A. W., \& Mudakir, Y. B. (2011). Analisis pengaruh jumlah penduduk, pdrb, ipm, pengangguran terhadap tingkat kemiskinan di kabupaten/kota Jawa Tengah. Semarang: Eprints.undip.ac.id.

Situmorang, A. P. (2019). 5-Strategi-pemerintahtekan-angka-kemiskinan. Diakses pada tanggal 18 Agustus 2019, dari https://www.liputan6.com/bisnis/read/3594321/ 5-strategi-pemerintah-tekan-angka-kemiskinan.

Suliswanto, M. S. W. (2010). Pengaruh produk domestik bruto (pdb) dan indeks pembangunan manusia (ipm) terhadap angka kemiskinan di Indonesia. Jurnal Ekonomi Pembangunan, 8(2), 357-366.

Susilowati, N. I., \& Hadi, S. (2017). Pengaruh alokasi dana desa, dana desa, belanja modal dan produk regional bruto terhadap kemiskinan kabupaten/kota di Jawa Timur. Jurnal Ilmu Ekonomi, 1(2), 514-526.

Suryawati, C. (2005). Memahami kemiskinan secara multi dimensional. Jurnal Manajemen Pelayanan Kesehatan, 8(3), 121-129.

Todaro, M. P. (2000). Pembangunan ekonomi di dunia ketiga. Edisi Ketujuh. Jakarta: Erlangga.

Undang-Undang Dasar Tahun 1945.

Undang-Undang Nomor 6 Tahun 2014 tentang Desa.

Widianto, A., Sedyautami, E. U., \& Nurmansyah, A. L. (2016). Pengaruh dana alokasi umum, dana alokasi khusus dan belanja modal terhadap pertumbuhan ekonomi dan tingkat kemiskinan, studi kasus pada kota Tegal. Monex: Journal Research Accounting Politeknik Tegal, 5(2), 170-176. 